\title{
Addition of Palm Oil in Diet of Dairy Ewes Reduces Saturates Fatty Acid and Increases Unsaturated Fatty Acids in Milk
}

\author{
Anderson Elias Bianchi', Talyta Zortea ${ }^{2}$, Chrystian Jassana Cazzarotto ${ }^{2}$, Gustavo Machado ${ }^{3}$, \\ Luis Gustavo Pellegrini ${ }^{4}$, Neila Silvia Pereira dos Santos Richards ${ }^{4}$, Matheus Dellaméa Baldissera ${ }^{5}$, \\ Aleksandro Schafer da Silva ${ }^{2}$, Alessandro Cazonatto Galvão ${ }^{6}$ \& Vicente de Paula Macedo ${ }^{7}$
}

\begin{abstract}
Background: Sheep milk production is becoming an important alternative in the agricultural sector. It is used principally to produce fine cheeses, yogurts, and ice creams, and these produced from sheep's milk are beneficial to human health. Previous study with palm oil shows increase in fat levels in sheep's milk. Our hypothesis for increased fat in milk is that palm oil increases lipid metabolism as well as tissue reserves. Sheep consuming this palm oil will have a change in the fatty acid profile of milk, increasing levels of unsaturated fatty acids. Therefore, the aim of this study was to determine the levels of cholesterol and triglycerides, as well as fatty acid profile of milk these ewes fed of palm oil.

Materials, Methods \& Results: Thirty-six lactating sheep were divided in four groups $(\mathrm{n}=9)$, with each group receiving various concentrations of palm oil in diet $(0 \%, 2 \%, 4 \%$, and $6 \%$ which corresponds to T $0,2,4$ and 6 , respectively). The diets in each treatment were isoproteic and isoenergetic. The experiment lasted 120 days, and blood and milk samples were collected on days 60 and 12 of the experiment. Blood was collected for seric analysis of lipid metabolism. Was collected milk samples and analyzed the content of saturated fatty acids (SFAs), monounsaturated fatty acids (MUFA), and polyunsaturated fatty acids (PUFA). An increase $(P<0.05)$ in triglyceride and coleterol levels in the serum of the animals that received the highest concentrations of palm oil in the diet (T4 and T6). The centesimal composition of fat, lactose, and protein in milk was not different at days 60 and $120(P>0.05)$ between groups, but numerically the animals in T4 and T6 had higher percentage of fat in milk. A decrease in milk SFA levels was observed on day 120 at T6. There was a significant reduction in caproic acid, caprylic acid, hendecanoic acid, lauric acid, and pentadecyl acid. The levels of palmitic acid (C16:0) increased when compared with the control group. Also at 150 days, it was observed a reduction in the percentage of area capric acid and myristic acid in animals that had higher doses of calcium salts in the diet, different from stearic acid, which increased. A variability in MUFA levels was observed during the evaluated periods, i.e. heptadecenoic acid decreased on days 60 and 120 for animals of T6; an increased content of elaidic acid was observed on day 60, and levels of vaccenic acid decreased on day 120 at 6\% palm oil. A decrease in PUFA levels was observed on day 60 at T6, specifically a significant reduction in alpha-linolenic and arachidonic acid, as well as levels of conjugated linoleic acid 1 decreased on day 120 for animals supplemented with $6 \%$ of palm oil.

Discussion: The addition of plama oil in the diet of dairy sheep increased seric levels of triglycerides and cholesterol, as well as positively altered the composition of fatty acids in milk, making a product healthier to the consumer. This study showed that the addition of $2 \%$ and $4 \%$ palm oil in the feed of dairy sheep promoted a decrease in several SFAs associated with coronoary heart disease after 60 days of treatment. On the other hand, the addition of $6 \%$ palm oil promoted an increase of total SFA levels after 60 days of treatment, while decreaseing total PUFA levels. This can be considered harmful to consumers, since several SFA are associated with coronary heart diseases, and several PUFA are linked with reductions in inflammation, stroke, oxidative stress and hepatic disorders. In summary, the consumption of sheep milk who received the diets with $2 \%$ and $4 \%$ of palm oil can exert beneficial effects for consumers, and may be an option for farmers to increase the milk yield of sheep, and to reduce the profile of saturated fatty acids in milk.
\end{abstract}

Keywords: palm oil, milk composition, sheep, fatty acids, health.

http://dx.doi.org/10.22456/1679-9216.85894 of Population Health and Pathobiology, College of Veterinary Medicine, North Carolina State University, Raleigh, NC, USA. ${ }^{4}$ Department of Food Production \& ${ }^{5}$ Department of Microbiology and Parasitology, UFSM, Santa Maria, RS, Brazil. ${ }^{6}$ Department of Food and Chemical Engineering, UDESC, Pinhalzinho, SC, Brazil. ${ }^{7}$ Department of Animal Science, UTFPR, Dois Vizinhos, PR, Brazil. CORRESPONDENCE: A.E. Bianchi [bianchi.zootecnista@gmail.com - Tel.: +55 (49) 2049-9565]. Departamento de Zootecnia - UFPR. Rua dos Funcionários n. 1540. CEP 80035-050 Curitiba, PR, Brazil. 


\section{INTRODUCTION}

Sheep milk production for human consumption is a relatively new phenomenon in Brazil. Compared with bovine milk, Brazilians drink relatively little sheep milk, although it possesses considerable nutritional and commercial value [30]. During lactation, sheep have high energy requirements, and their feeding is critical to meet this energetic demand [4]. Lactating ewes require supplemental fat sources to satisfy their high energy requirements in the context of limited food intake capacity during lactation, and to maintain minimum dietary fiber intake for ruminal fermentation [9]. Investigators have used vegetable fats, including essential oils and seed oils, to help satisfy the energetic requirements in lactating animals. This method is ineffective in some cases, since high levels of fat provided in the diet reduce the digestion of dry matter in the rumen, leading to reduced energy availability [15].

Vegetable fat supplementation promotes increased fat content, and modifies milk fat composition. Palm oil is composed of SFAs (50\%: 44\% is palmitic acid and 5\% is stearic acid) and unsaturated fatty acids (UFAs), include $40 \%$ oleic acid $10 \%$ polyunsaturated linoleic acid and alpha-linolenic acid [12,34]. According to the study, the addition of palm oil in the form of calcium salts in the diet increased milk production (4\% and 6\% palm oil), as well as increasing fat levels in the milk [6]. This can affect the lipidic metabolism and fatty acid profile in milk. Therefore, the aim of this study was to determine the levels of cholesterol and triglycerides, as well as fatty acid profile of milk these ewes fed with isoproteic and isoenergetic diet content different levels of palm oil.

\section{MATERIALS AND METHODS}

\section{Animals and experimental design}

Thirty-six lactating Lacaune sheep were randomly selected; animals with approximately the same body weight ( $56 \pm 4 \mathrm{~kg}$ ), age between $2-4$ years, similar number of offspring (second lactation), and milk production were used current study [4]. The diets and concentration of palm oil in the diet was showed in Table 1. Protected fat from palm oil (Ca-salts or Casoap) was as follows: $0 \%$ (T0), $2 \%$ (T2), $4 \%$ (T4) and $6 \%$ (T6), therefore, four treatments were used in the experimental design.
Each treatment included nine animals housed in pens of $24 \mathrm{~m}^{2}$, in a covered shed. Animals were fed twice per day (07:00 and 18:00), individually, with a concentrate containing protected fat $\mathrm{Ca}$-salts, followed by corn silage, with ad libitum access to water. The amount of concentrate given was adjusted according to the volume of milk produced by each animal and its body weight (up to $1.4 \mathrm{~kg}$ for day), which decreased towards to a minimum of $0.6 \mathrm{~kg} \mathrm{day}^{-1}$ at the end of the experiment, when body weight was also reduced. Each animal also received $2.5 \mathrm{~kg}$ of corn silage every meal, which was substantial, since always found leftovers that were collected and weighed, as described [4]. The chemical composition [8] of the diets are described in Table 1.

\section{Cholesterol and triglycerides levels}

Blood samples ( $5 \mathrm{~mL}$ per ewe) were individually collected on days 60 and 120 of the experimental period. Blood allocated to tubes without anticoagulant was centrifuged at $3500 \mathrm{~g}$ for $10 \mathrm{~min}$ to obtain serum. The serum levels of cholesterol and triglycerides were evaluated in a semi-automatic analyzer (TP Analyzer Plus $)^{1}$ using commercial kits ${ }^{2}$ [4].

\section{Milk fatty acid analysis}

To evaluate the fatty acid composition, milk samples $(50 \mathrm{~mL}$ per ewe) were individually collected on days 60 and 120 of the experimental period, during morning milking. Samples were collected in Falcon tubes without preservatives, and were stored at $-20^{\circ} \mathrm{C}$ until analysis. These collection dates were defined because it was observed a centesimal increase in milk fat levels in the initial lactation phase, as previously published [6].

Milk samples were thawed under refrigeration $\left(7 \pm 1^{\circ} \mathrm{C}\right)$, homogenized, and processed for extraction and esterification of lipids. The lipids were extracted according the technique previously described [7]. Briefly, $4 \mathrm{~g}$ of milk was homogenized in $8 \mathrm{~mL}$ chloroform, $16 \mathrm{~mL}$ ethanol, and $3 \mathrm{~mL}$ distilled water. Samples were centrifuged for $5 \mathrm{~min}$, and the precipitates were stored in Falcon tubes containing $1 \mathrm{~g}$ of sodium sulfate, in order to remove traces of water. The homogenates were clarified by filtration through funnel and filter paper impregnated with $1 \mathrm{~g}$ sodium sulfate. Finally, $1.5 \mathrm{~mL}$ of the filtrates was transferred to sealed test tubes for drying in a vacuum evaporator. 
The extracted fat was esterified according the method described by Hartman and Lago [18]. The fat was added to $0.5 \mathrm{~mL}$ potassium hydroxide $(0.4 \mathrm{M})$ in methanol, vortexed briefly, and heated to $100^{\circ} \mathrm{C}$ for $10 \mathrm{~min}$. After cooling to room temperature, $1.5 \mathrm{~mL}$ of sulfuric acid ( $1 \mathrm{M}$ ) was added to the methanol, and the mixture was heated to $100^{\circ} \mathrm{C}$ for $10 \mathrm{~min}$, after which it was cooled again to room temperature. Next, the fat was mixed with $2 \mathrm{~mL}$-hexane (chromatographic grade) for 20 min to achieve phase separation. The hexane solution containing the fatty acid methyl esters (FAME) was collected and stored at $-20^{\circ} \mathrm{C}$ until chromatography.

The esters were analyzed by gas chromatography (Agilent Technologies 6890N) ${ }^{3}$, equipped a flame ionization detector. One $\mu \mathrm{L}$ of sample was injected in split mode (50:1) in the injection port at $250^{\circ} \mathrm{C}$. Nitrogen was used as a carrier gas at $0.9 \mathrm{~mL} \mathrm{~min}^{-1}$. The fused silica capillary column SP-2560 ${ }^{\mathrm{TM}}(100 \mathrm{~m}$ length, $0.25 \mathrm{~mm}$ internal diameter, $0.25 \mu \mathrm{m}$ film thickness ${ }^{4}$ ) was used for FAME. The column program started at $35^{\circ} \mathrm{C}$ for $2 \mathrm{~min}$, after the temperature increased $10^{\circ} \mathrm{C}$ $\mathrm{min}^{-1}$ to $150^{\circ} \mathrm{C}$, remaining in this temperature for $2 \mathrm{~min}$. Then, the temperature increased $2^{\circ} \mathrm{C} \mathrm{min}^{-1}$ up to $200^{\circ} \mathrm{C}$ remaining for $2 \mathrm{~min}$. Finally, the temperature increased $2^{\circ} \mathrm{C} \mathrm{min}^{-1}$ up to $220^{\circ} \mathrm{C}$, remaining isothermal for 21 min, totaling $73.5 \mathrm{~min}$. The detector temperature was maintained constant at $280^{\circ} \mathrm{C}$. Fatty acids were identified by comparison retention times of experimental peaks with those from reference standards: Supelco
37 Component FAME Mix, conjugated linoleic acid (CLA) mixture of 9-cis, 11-trans and 10-trans, and 12-cis isomers and octadecadienoic acid methyl esters (C18: 2), all from Supelco ${ }^{4}$. Retention times and areas were computed automatically by GC Solution software. The results were expressed in percentage of area.

\section{Statistical analysis}

SFA, MUFA and PUFA were analyzed using descriptive statistics for contingency variables, and to obtain median and amplitude. It was calculated the median, and minimum and maximum values from scattered data as central tendency measure. All variables were evaluated by a normality test (Shapiro-Wilk). In the absence of data normality, it was performed a non-parametric test. For evaluation of the influence of time on the measured parameters (repeated measure), it was used a non-parametric Friedman test for all combinations of fatty acids and $\Sigma$ SFA, $\Sigma$ MUFA and $\Sigma$ PUFA, considering the influence of groups, as well as the blocks, as needed. The Bonferroni test was used for multiple comparisons between the days of collection and groups. Alterations over time were compared among the four groups. The Kruskal-Wallis test was used to verify the difference between days of collection (60 to 120 days). Statistical significance was set at $P<$ 0.05. All analyses were performed using R v.2.15.2 (R Development Core Team, 2012) software.

Table 1. Ingredients and chemical composition of the experimental concentrates (DM\%) to sheep during lactation.

\begin{tabular}{ccccc}
\hline Ingredient & T0 & T2 & T4 & T6 \\
\hline Corn ground & 51.0 & 41.0 & 30.0 & 19.0 \\
Soybean meal & 43.0 & 43.0 & 41.0 & 40.0 \\
Wheat bran & 2.0 & 10.0 & 21.0 & 31.0 \\
Calcium soap (Palm oil) & 0.0 & 2.0 & 4.0 & 6.0 \\
Vitamin and mineral & 2.5 & 2.5 & 2.5 & 2.5 \\
Calcitic limestone & 1.0 & 1.0 & 1.0 & 1.0 \\
Sodium bicarbonate & 0.5 & 0.5 & 0.5 & 0.5 \\
\hline & Diet chemical composition - concentrate (\%) & & \\
\hline Crude protein & 23.35 & 23.41 & 23.63 & 23.80 \\
Ethereal extract & 2.25 & 2.70 & 2.89 & 3.92 \\
Unity & 13.65 & 15.49 & 13.67 & 13.01 \\
Ashes & 6.52 & 6.66 & 9.22 & 8.55 \\
Crude fiber & 86.25 & 84.76 & 86.22 & 86.87 \\
Total digestible nutrients (TDN) & 73.4 & 73.9 & 73.7 & 73.8 \\
\hline
\end{tabular}

Note: Corn silage chemical composition: Crude Protein $=7.36 \%$; Ethereal extract $=3.56 \%$; Unity: $68.66 \%$; Ashes: $1.15 \%$; Crude fiber: $31.47 \%$; and $\mathrm{TDN}=66.76 \%$ 


\section{RESULTS}

Results of the triglyceride and coleterol levels were showed in Figure 1. In the two evaluated moments there was an increase $(P<0.05)$ in triglyceride and coleterol levels in the serum of the animals that received the highest concentrations of palm oil in the $\operatorname{diet}$ (T4 and T6).

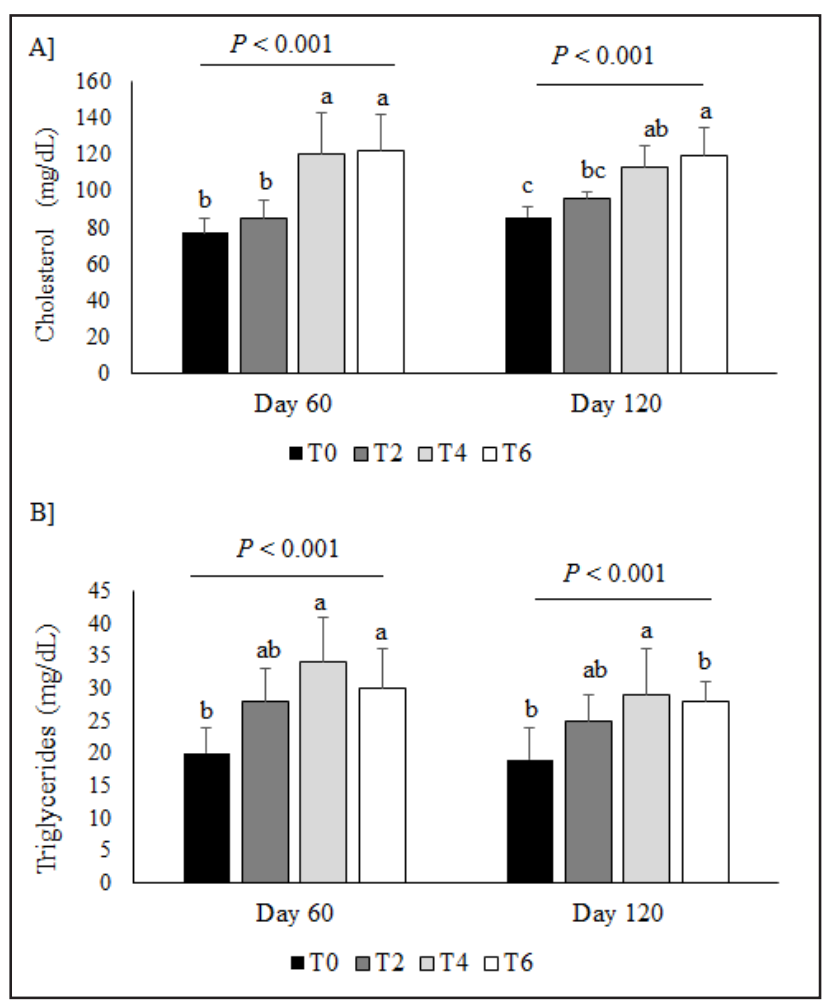

Figure 1. Levels of cholesterol and triglycerides.in dairy sheep receiving different diets based on palm oil. Different letters (a, b, c) show differences between treatments at each moment (day 60 or 120).

The centesimal composition of fat $(\mathrm{F})$, lactose $(\mathrm{L})$, and protein $(\mathrm{P})$ in milk was not different at days 60 and $120(P>0.05)$ between groups, but numerically the animals in groups T4 and T6 had higher percentage of fat in milk. On days 60 and 120, the values varied as follows: $6.25-6.79 \%(\mathrm{~F}), 4.25-4.86 \%(\mathrm{~L})$, and $4.08-5.24 \%(\mathrm{P})$.

A decrease in milk SFA levels was observed on day 120 at T6 (concentration of $6 \%$ of palm oil). There was a significant reduction in caproic acid (C6:0), caprylic acid (C8:0), hendecanoic acid (C11:0), lauric acid (C12:0), and pentadecyl acid (C15:0). The levels of palmitic acid (C16:0) increased when compared with the control group (Table 2). Also at 150 days, it was observed a reduction in the percentage of area capric acid (C10:0) and myristic acid (C14:0) in animals that had higher doses of calcium salts in the diet, different from stearic acid (C18:0), which increased.

A variability in MUFA levels was observed during the evaluated periods (Table 3 ). Heptadecenoic acid (C17:1 n-7) decreased on days 60 and 120 for animals of T6. An increased content of elaidic acid (C18: $1 \mathrm{n}-9 \mathrm{t}$ ) was observed on day 60, compared with control. However, levels of vaccenic acid (C18: $1 \mathrm{n}-7 \mathrm{t})$ decreased on day 120 at $6 \%$ palm oil, compared with the control group (Table 3).

A decrease in PUFA levels was observed on day 60 at T6, specifically a significant reduction in alpha-linolenic (C18:3 n-3) and arachidonic acid (C20:4 n-6), compared with control. Similarly, levels of conjugated linoleic acid 1 (CLA1) [C18:2 c9, t11] decreased on day 120 for animals supplemented with $6 \%$ of palm oil compared with control (Table 4).

$\Sigma$ SFA and $\Sigma$ PUFA differed between groups on day 60 , and the difference occurred between group A and D (Tables 2 and 4). $\Sigma$ MUFA did not differ between groups $(P>0.05)$. Over time, $\Sigma$ MUFA differed of day 60 to 150 , i.e., for groups A and B, MUFA levels were significantly reduced of day 150 (data not shown). Over time, for the four groups, no difference $(P>0.05)$ from day 60 to 150 was observed for any of the SFA, MUFA and PUFA identified in sheep's milk (data not shown). It was observed a negative correlation between $\Sigma$ SFA and $\Sigma$ MUFA levels ( $\mathrm{r}=-0.89 ; P<0.001)$. There was also a negative correlation between $\Sigma$ SFA versus $\Sigma$ FUPA $(r=-0.32 ; P=0.001)$ [Figure 2]. No correlation was observed between $\Sigma$ MUFA and $\Sigma$ PUFA $(P>0.05)$.

Even with $100 \mathrm{~m}$ capillary columns, single runs for each milk sample did not allow a complete separation of octadecenoic and octadecadienoic (both conjugated and non-conjugated) isomers. Is quite difficult to separate trans-vaccenic acid (which usually coelutes with other C18:1 isomers) and rumenic acid (which usually coelutes with other CLA isomers). It was suppose that vaccenic acid and rumenic acid coeluted with other FAs, and therefore coelutions may have occurred. 
A.E. Bianchi, T. Zortea, C.J. Cazzarotto, et al. 2018. Addition of Palm Oil in Diet of Dairy Ewes Reduces Saturates Fatty Acid and Increases Unsaturated Fatty Acids in Milk.

Table 2. Median and range (minimum and maximum) of saturated fatty acids (SFA) profile in milk of sheep fed with different concentration of palm oil. Results in percentage of area (\%).

\begin{tabular}{|c|c|c|c|c|c|c|}
\hline \multirow[t]{2}{*}{ Variable } & \multirow[t]{2}{*}{ Days } & \multicolumn{5}{|c|}{ Median \pm range $(\min -\max )^{*}$} \\
\hline & & T0 $(n=9)$ & $\mathrm{T} 2(\mathrm{n}=9)$ & T3 $(n=9)$ & $\mathrm{T} 4(\mathrm{n}=9)$ & $P$-value \\
\hline \multirow{2}{*}{$\mathrm{C} 4: 0$} & 60 & $0.87(0.6-1.1)$ & $0.93(0.0-1.1)$ & $0.88(0.6-1.0)$ & $0.94(0.7-1.1)$ & 0.83 \\
\hline & 120 & $0.94(0.1-1.0)$ & $0.94(0.4-1.0)$ & $0.95(0.2-1.0)$ & $0.17(0.0-1.1)$ & 0.08 \\
\hline \multirow{2}{*}{ C6:0 } & 60 & $1.07(0.8-1.3)$ & $1.02(0.3-1.1)$ & $1.08(0.5-1.3)$ & $1.07(0.9-1.1)$ & 0.44 \\
\hline & 120 & $1.24(0.6-1.3)^{\mathrm{a}}$ & $1.21(0.2-1.3)^{\mathrm{ab}}$ & $1.15(0.3-1.3)^{\mathrm{ab}}$ & $0.40(0.1-1.2)^{\mathrm{b}}$ & $0.008 *$ \\
\hline \multirow{2}{*}{$\mathrm{C} 8: 0$} & 60 & $1.38(1.0-1.8)$ & $1.19(0.4-1.4)$ & $1.36(0.2-1.6)$ & $1.33(1.0-1.4)$ & 0.20 \\
\hline & 120 & $1.67(1.4-1.9)^{\mathrm{a}}$ & $1.54(0.8-1.6)^{\mathrm{ab}}$ & $1.45(1.1-1.6)^{\mathrm{ab}}$ & $0.99(0.7-1.5)^{\mathrm{b}}$ & $0.001 *$ \\
\hline \multirow{2}{*}{ C10:0 } & 60 & $5.97(3.7-8.3)$ & $4.63(3.8-5.8)$ & $5.31(1.8-6.6)$ & $5.27(3.5-6.0)$ & 0.24 \\
\hline & 120 & $7.20(5.2-7.6)^{\mathrm{a}}$ & $5.96(5.0-6.6)^{\mathrm{b}}$ & $5.70(5.1-6.9)^{\mathrm{bc}}$ & $5.20(4.2-6.2)^{\mathrm{c}}$ & $0.001 *$ \\
\hline \multirow{2}{*}{ C11:0 } & 60 & $0.16(0.07-1.6)^{\mathrm{a}}$ & $0.08(0.0-0.5)^{\mathrm{b}}$ & $0.12(0.0-0.1)^{\mathrm{ab}}$ & $0.11(0.0-3.6)^{\mathrm{ab}}$ & 0.04 \\
\hline & 120 & $0.25(0.1-0.4)^{\mathrm{a}}$ & $0.15(0.1-0.2)^{\mathrm{ab}}$ & $0.16(0.0-0.2)^{\mathrm{ab}}$ & $0.10(0.0-0.2)^{\mathrm{b}}$ & $0.001 *$ \\
\hline \multirow{2}{*}{ C12:0 } & 60 & $4.30(2.4-6.5)$ & $3.58(2.7-3.9)$ & $3.92(1.7-4.4)$ & $3.56(0.0-4.4)$ & 0.21 \\
\hline & 120 & $5.20(3.4-5.9)^{\mathrm{a}}$ & $3.95(3.3-4.3)^{\mathrm{b}}$ & $3.71(3.7-5.0)^{\mathrm{bc}}$ & $3.61(3.3-4.0)^{\mathrm{c}}$ & $0.001 *$ \\
\hline \multirow{2}{*}{$\mathrm{C} 14: 0$} & 60 & $12.19(8.6-15.7)$ & $11.4(10.2-13.6)$ & $11.2(6.3-13.3)$ & $11.7(9.7-13.4)$ & 0.42 \\
\hline & 120 & $11.08(8.2-13.8)^{\mathrm{a}}$ & $9.96(9.1-12.1)^{\mathrm{b}}$ & $9.47(8.3-13.6)^{\mathrm{ab}}$ & $9.98(9.6-11.0)^{\mathrm{ab}}$ & $0.01 *$ \\
\hline \multirow{2}{*}{$\mathrm{C} 15: 0$} & 60 & $1.15(0.0-1.8)$ & $0.95(0.0-1.2)$ & $1.04(0.0-1.1)$ & $1.05(0.0-1.3)$ & 0.72 \\
\hline & 120 & $1.66(1.1-20.6)^{\mathrm{a}}$ & $1.17(1.0-1.2)^{\mathrm{b}}$ & $1.17(0.8-1.2)^{\mathrm{b}}$ & $1.02(0.9-1.3)^{\mathrm{c}}$ & $0.001 *$ \\
\hline \multirow{2}{*}{ C16:0 } & 60 & $31.0(25.1-32.9)^{\mathrm{a}}$ & $32.8(30.2-35.8)^{\mathrm{a}}$ & $32.4(28.8-35.4)^{\mathrm{a}}$ & $35.5(31.4-37.2)^{b}$ & $0.01 *$ \\
\hline & 120 & $29.8(27.38-33.1)^{\mathrm{a}}$ & $33.1(32.5-35.2)^{b}$ & $33.5(31.9-35.1)^{b}$ & $37.0(34.0-38.4)^{\mathrm{c}}$ & $0.01 *$ \\
\hline \multirow{2}{*}{$\mathrm{C} 17: 0$} & 60 & $0.0(0.0-0.0)$ & $0.0(0.0-0.0)$ & $0.00(0.0-0.0)$ & $0.0(0.0-0.0)$ & - \\
\hline & 120 & $0.34(0.0-1.0)$ & $0.68(0.0-0.7)$ & $0.00(0.0-0.6)$ & $0.62(0.0-0.7)$ & 0.07 \\
\hline \multirow{2}{*}{ C18:0 } & 60 & $8.85(0.0-14.5)$ & $9.38(8.4-12.5)$ & $9.58(7.4-13.0)$ & $10.2(8.0-10.5)$ & 0.68 \\
\hline & 120 & $9.39(7.3-11.5)^{\mathrm{a}}$ & $11.25(8.2-11.9)^{\mathrm{ab}}$ & $10.33(8.3-13.5)^{\mathrm{ab}}$ & $11.28(9.1-12.5)^{\mathrm{b}}$ & $0.02 *$ \\
\hline \multirow{2}{*}{$\mathrm{C} 20: 0$} & 60 & $0.22(0.0-0.3)$ & $0.21(0.0-0.2)$ & $0.22(0.1-0.2)$ & $0.10(0.0-0.2)$ & 0.28 \\
\hline & 120 & $0.20(0.0-0.2)$ & $0.23(0.1-0.2)$ & $0.21(0.1-0.2)$ & $0.19(0.0-0.2)$ & 0.06 \\
\hline \multirow{2}{*}{$\mathrm{C} 22: 0$} & 60 & $0.07(0.0-1.2)$ & $0.06(0.0-0.1)$ & $0.06(0.0-0.1)$ & $0.02(0.0-0.0)$ & 0.41 \\
\hline & 120 & $0.08(0.0-0.6)$ & $0.08(0.0-0.6)$ & $0.08(0.0-0.7)$ & $0.06(0.0-0.0)$ & 0.38 \\
\hline \multirow{2}{*}{ C23:0 } & 60 & $0.00(0.0-0.5)$ & $0.00(0.0-0.5)$ & $0.00(0.0-0.3)$ & - & 0.34 \\
\hline & 120 & $0.36(0.0-0.6)$ & $0.31(0.0-0.5)$ & $0.45(0.0-0.5)$ & $0.16(0.0-0.4)$ & 0.25 \\
\hline \multirow{2}{*}{$\mathrm{C} 24: 0$} & 60 & $0.00(0.0-0.0)$ & $0.00(0.0-0.0)$ & $0.00(0.0-0.3)$ & $0.00(0.0-0.1)$ & 0.96 \\
\hline & 120 & $0.24(0.0-0.7)$ & $0.08(0.0-0.5)$ & $0.44(0.3-0.5)$ & $0.15(0.0-0.5)$ & 0.26 \\
\hline \multirow{2}{*}{$\Sigma \mathrm{SFA}$} & 60 & $67.23^{\mathrm{b}}$ & $66.23^{\mathrm{ab}}$ & $67.17^{\mathrm{ab}}$ & $70.90^{\mathrm{a}}$ & 0.03 \\
\hline & 120 & 69.65 & 70.68 & 68.85 & 70.97 & 0.49 \\
\hline
\end{tabular}

NOTE: Median followed by same letter in the same line do not differ significantly considering $P<0.05$. Obs.: butyric acid (C4:0), hexanoic acid (C6:0), caprylic acid (C8:0), capric acid (C10:0), undecanoic acid (C11:0), lauric acid (C12:0), myristic acid (C14:0), pentadecanoin acid (C15:0), palmitic acid (C16:0), heptadecanoic acid (C17:0), stearic acid (C18:0), arachidic acid (C20:0) behenic acid (C22:0), ticosanoic acid (C23:0) and lignoceric acid (C24:0). 
A.E. Bianchi, T. Zortea, C.J. Cazzarotto, et al. 2018. Addition of Palm Oil in Diet of Dairy Ewes Reduces Saturates Fatty Acid and Increases Unsaturated Fatty Acids in Milk.

Acta Scientiae Veterinariae. 46: 1608.

Table 3. Median and range (minimum and maximum) of monounsaturated fatty acids (MFA) in milk of sheep fed with different concentration of palm oil. Results in percentage of area $(\%)$.

\begin{tabular}{ccccccc}
\hline Variable & Day & \multicolumn{7}{c}{ Median \pm range (min-max $)^{*}$} \\
\hline \multirow{2}{*}{ C14:1 n-5 } & 60 & $0.32(0.1-0.5)$ & $0.29(0.1-0.3)$ & $0.26(0.1-0.4)$ & $0.28(0.0-0.4)$ & 0.76 \\
& 120 & $0.14(0.0-0.2)$ & $0.12(0.0-0.2)$ & $0.13(0.0-0.2)$ & $0.13(0.0-0.7)$ & 0.58 \\
C16:1 n-7 & 60 & $1.54(0.8-1.8)$ & $1.59(0.9-2.1)$ & $1.54(1.1-2.2)$ & $1.73(1.1-2.6)$ & 0.72 \\
& 120 & $1.14(0.0-1.5)$ & $1.29(0.0-1.9)$ & $1.05(0.7-1.5)$ & $1.15(0.0-0.1)$ & 0.65 \\
C17:1 n-7 & 60 & $0.32(0.1-0.4)^{\mathrm{a}}$ & $0.29(0.1-0.4)^{\mathrm{ab}}$ & $0.26(0.1-0.3)^{\mathrm{ab}}$ & $0.22(0.0-0.2)^{\mathrm{b}}$ & $0.01^{*}$ \\
& 120 & $0.26(0.0-0.4)^{\mathrm{a}}$ & $0.16(0.0-0.2)^{\mathrm{ab}}$ & $0.16(0.0-0.2)^{\mathrm{ab}}$ & $0.12(0.0-0.2)^{\mathrm{b}}$ & $0.01^{*}$ \\
$\mathrm{C} 18: 1 \mathrm{n}-9 \mathrm{t}$ & 60 & $0.44(0.0-0.5)^{\mathrm{a}}$ & $0.55(0.4-0.6)^{\mathrm{ab}}$ & $0.52(0.4-0.9)^{\mathrm{ab}}$ & $0.67(0.3-0.8)^{\mathrm{b}}$ & $0.001^{*}$ \\
& 120 & $0.57(0.5-0.8)$ & $0.57(0.4-0.6)$ & $0.60(0.4-0.8)$ & $0.60(0.5-0.7)$ & 0.62 \\
C18:1 n-7t & 60 & $2.92(2.1-4.2)$ & $2.50(2.2-2.8)$ & $2.33(2.0-3.1)$ & $2.36(1.6-2.9)$ & 0.15 \\
& 120 & $3.50(1.9-6.0)^{\mathrm{a}}$ & $2.86(1.8-6.0)^{\mathrm{ab}}$ & $3.13(1.2-6.1)^{\mathrm{ab}}$ & $2.34(1.6-2.9)^{\mathrm{b}}$ & $0.03^{*}$ \\
C18:1 n-9c & 60 & $21.25(17.5-27.3)$ & $22.3(19.7-29.5)$ & $22.93(19.7-24.9)$ & $22.39(14.5-24.4)$ & 0.42 \\
& 120 & $18.71(15.5-20.6)$ & $19.1(16.9-21.9)$ & $19.18(17.2-21.6)$ & $19.28(16.9-30.8)$ & 0.57 \\
C20:1 n-9 & 60 & $0.06(0.0-1.4)$ & $0.08(0.0-0.7)$ & $0.08(0.0-0.1)$ & $0.07(0.0-0.1 .0)$ & 0.25 \\
& 120 & $0.08(0.0-0.7)$ & $0.08(0.0-0.6)$ & $0.14(0.0-0.6)$ & $0.08(0.0-0.8)$ & 0.10 \\
\hline \multirow{2}{*}{$\Sigma$ MUFA } & 60 & 26.85 & 27.60 & 27.92 & 27.72 & 0.54 \\
& 120 & 24.10 & 24.18 & 24.39 & 23.70 & 0.73 \\
\hline
\end{tabular}

NOTE: Median followed by same letter in the same line do not differ significantly considering $P<0.05$. Obs.: myristoleic acid (C14:1 n-5), palmitoleic acid (C16:1 n-7), heptadecenoic acid (C17:1 n-7), elaidic acid (C18:1 n-9t), vaccenic acid (C18:1 n-7t), oleic acid (C18:1 n-9C), eicosamonoenoic acid (C20:1 n-9).

Table 4. Median and range (minimum and maximum) of poliunsaturated fatty acids (PFA) in milk of sheep fed with different concentration of palm oil. Results in percentage of area $(\%)$.

\begin{tabular}{ccccccc}
\hline Variable & Days & \multicolumn{7}{c}{ Median \pm range $(\text { min-max })^{*}$} \\
\hline & & $\mathrm{T} 0(\mathrm{n}=9)$ & $\mathrm{T} 2(\mathrm{n}=9)$ & $\mathrm{T} 4(\mathrm{n}=9)$ & $\mathrm{T} 6(\mathrm{n}=9)$ & P-value \\
\hline \multirow{2}{*}{ C18:2 n-6t } & 60 & $0.24(0.0-0.2)$ & $0.20(0.0-0.2)$ & $0.18(0.0-0.3)$ & $0.22(0.0-0.2)$ & 0.65 \\
& 120 & $0.15(0.0-0.5)$ & $0.0(0.0-0.0)$ & $0.0(0.0-0.0)$ & $0.0(0.0-0.0)$ & - \\
C18:2 n-6c & 60 & $2.60(1.8-37.9)$ & $2.26(0.0-6.2)$ & $2.52(1.8-8.8)$ & $2.16(1.8-2.9)$ & 0.29 \\
& 120 & $3.60(2.4-5.4)$ & $3.08(1.9-4.2)$ & $3.42(2.7-5.4)$ & $3.29(2.7-4.4)$ & 0.18 \\
C18:3 n-6 & 60 & $0.08(0.0-1.4)$ & $0.08(0.0-0.5)$ & $0.07(0.0-1.0)$ & $0.06(0.0-0.4)$ & 0.06 \\
& 120 & $0.09(0.0-0.1)$ & $0.11(0.0-0.7)$ & $0.10(0.0-0.4)$ & $0.08(0.0-0.6)$ & 0.45 \\
C18:3 n-3 & 60 & $0.22(0.1-0.3)^{\mathrm{a}}$ & $0.18(0.1-0.6)^{\mathrm{ab}}$ & $0.20(0.1-0.7)^{\mathrm{ab}}$ & $0.14(0.0-0.2)^{\mathrm{c}}$ & $0.01^{*}$ \\
& 120 & $0.30(0.2-0.5)$ & $0.26(0.1-0.4)$ & $0.31(0.2-0.5)$ & $0.32(0.2-0.5)$ & 0.06 \\
C18:2 c9, t11 CLA1 & 60 & $0.88(0.4-1.2)$ & $0.94(0.4-1.0)$ & $0.89(0.5-1.1)$ & $0.76(0.0-1.0)$ & 0.37 \\
& 120 & $0.86(0.6-1.8)^{\mathrm{ab}}$ & $0.74(0.5-1.0)^{\mathrm{a}}$ & $0.77(0.2-0.9)^{\mathrm{b}}$ & $0.46(0.0-0.6)^{\mathrm{c}}$ & $0.001^{*}$ \\
C18:2 c12, t10 CLA2 & 60 & $0.20(0.0-1.6)$ & $0.04(0.0-0.4)$ & $0.15(0.0-0.4)$ & $0.12(0.0-0.4)$ & 0.67 \\
& 120 & $0.00(0.0-0.6)$ & $0.00(0.0-0.5)$ & $0.32(0.0-0.5)$ & $0.00(0.0-0.3)$ & 0.27 \\
C20:4 n-6 & 60 & $0.23(0.0-0.4)^{\mathrm{a}}$ & $0.18(0.0-0.2)^{\mathrm{ab}}$ & $0.18(0.1-0.2)^{\mathrm{ab}}$ & $0.16(0.0-0.2)^{\mathrm{b}}$ & $0.02^{*}$ \\
& 120 & $0.23(0.1-0.3)^{\mathrm{a}}$ & $0.18(0.1-1.7)^{\mathrm{b}}$ & $0.19(0.1-0.2)^{\mathrm{ab}}$ & $0.20(0.1-0.2)^{\mathrm{ab}}$ & 0.04 \\
C20:5 n-3 & 60 & $0.0(0.0-0.0)$ & $0.0(0.0-0.0)$ & $0.0(0.0-0.0)$ & $0.0(0.0-0.0)$ & - \\
& 120 & $0.18(0.0-0.4)$ & $0.01(0.0-0.4)$ & $0.02(0.0-0.3)$ & $0.20(0.0-0.4)$ & 0.24 \\
C22:6 n-3 & 60 & $0.16(0.0-0.3)$ & $0.02(0.0-0.3)$ & $0.04(0.0-0.3)$ & $0.21(0.0-0.3)$ & 0.34 \\
& 120 & $0.02(0.0-0.4)$ & $0.01(0.0-0.4)$ & $0.0(0.0-0.0)$ & $0.0(0.0-0.0)$ & 0.29 \\
\hline I PUFA & 60 & $4.61^{\mathrm{a}}$ & $3.90^{\mathrm{ab}}$ & $4.23^{\mathrm{ab}}$ & $3.83^{\mathrm{b}}$ & $0.01^{*}$ \\
& 120 & 5.43 & 4.39 & 5.13 & 4.55 & 0.24 \\
\hline
\end{tabular}

NOTE: Median followed by same letter in the same line do not differ significantly considering $P<0.05$. Obs.: acid trans-linolenic (C18:2 n-6t), acid cys-linolenic (C18:2 n-6c), acid gamma-linolenic (C18:3 n-6), acid alpha-linolenic (C18:3 3n-3), conjugated linoleic acid 1 (CLA1) (C18:2 c9, t11), conjugated linoleic acid 2 (CLA2) (C18:2 c12, t10), arachidonic acid (C20: 4 n-6), pentaenoic acid (C20:5 n-3) and docosahexaenoic acid (C22: 6 n-3). 


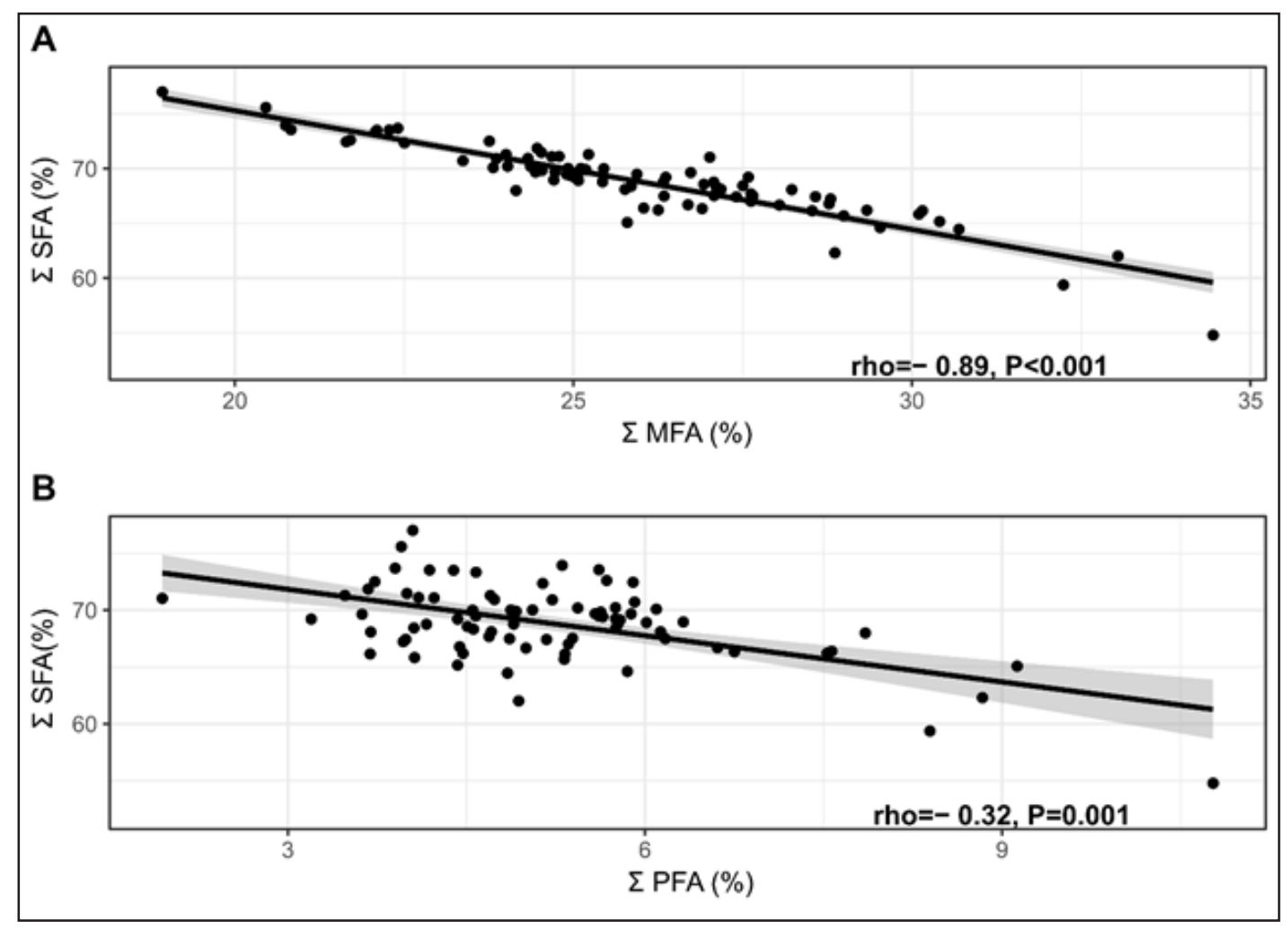

Figure 2. Spearman rank correlation between the sums of fatty acids (\%). The blue line represents the distribution trend; grey is $95 \%$ confidence interval.

\section{DISCUSSION}

Dairy sheep fed with palm oil showed alterations in the composition of their milk fatty acid composition in current study, and this can be associated with alterations in digestability, nutrient intake and rumen fermentation during dietary supplementation with palm oil [1,2], as well as increased lipid metabolism, which elevated the seric levels of triglycerides and cholesterol. A study conducted by researchers [1] demonstrated that diets for goats supplemented with $5 \%$ of palm oil enhanced the consumption of ration, improve digestibility of organic matter, protein and fat, as well as reduced the ruminal ammonia nitrogen concentration. Moreover, other study demonstrated that diet supplemented with $8 \%$ of palm oil increase nutrient intake (ether extract) and apparent digestibility (ether extract) of goats [2]. This same study demonstrated that diet containing $8 \%$ of palm oil increased the intake of C16:0, C16:1 C18-0, C18:1n-9, C18:2n-6, C18:3n-3 and total fatty acid content, without alterations in the intake of C12:0 and C14:0 fatty acids. Regarding digestibility, the C16:1, C18:1n-9, C18:2n-6, C18:3n-3 and total fatty acid were higher compared to control diet, but was lower for C18:0 and without altera- tions for C12:0, C14:0 and C16:0. Also, these authors evaluated the ruminal fatty acid content, demonstrating that addition of palm oil in the diet decreased the content of C12:0, C14:0, C14:1, C15:0, C16:1, C18:1 trans-11, C18:2n-6, C20:4n-6, total n-6 fatty acid, while the content of C18:0, 18:3n-3, C22:5n-3, C22:6n-3, SFA, and total $\mathrm{n}-3$ fatty acids increased. According to these authors, the reduction in short and medium-chain fatty acids may be associated with extenuation of long-chain fatty acid ruminal biohydrogenation, and consequently, inhibition of acetyl-CoA carboxylase, the enzyme responsible for fatty acids synthesis in the mammary glands, similarly to observed by researchers [5] in the fatty acid profile of yogurt from sheep supplemented with palm oil. In our study, it was observed no difference between groups and between times with respect to UFA/SFA. However, with respect to length of experiment (60-120 days), it was observed a dependence of PUFA levels with time (Friedman $=28.45, P<0.001)$. The mechanism by which lipid supplementation reduces consumption is not well understood, but may involve effects on ruminal fermentation, intestinal motility, palatability, release of intestinal hormones, and fatty oxidation [3, 11]. Palm oil $(10 \%)$ in the diet of sheep depresses ruminal clearance 
of dry matter, organic matter, and crute protein [4]. Study found that canola oil supplementation does not alter milk production in goats [26]. A similar result was reported in other reseach using licuri (3\%) and mamona (5\%) oils [32]. The supplementation with palm oil alters parameters linked with digestibility and intake of fatty acid in goats, as well as altering the content of fatty acids in the rumen, wich can explain the alterations on milk fatty acid composition observed in this study.

Dairy sheep fed with $6 \%$ oil palm showed alterations in the composition of their milk fatty acid composition in study present. Most of SFAs decreased with diet of $6 \%$ palm oil, in disagreement with the findings of researchers [2] in meat (Triceps brachii muscle) of goats supplemented with $8 \%$ of palm oil. However, is important emphasize that this difference can be associated with difference of concentration of palm oil provided in the diet, as well as in the fatty acids used to calculate the total SFAs, since these authors considered only the of C12:0, C14:0, C15:0, C16:0 and C18:0 fatty acids [2]. The suppression of $\mathrm{C} 12-\mathrm{C} 15$ has been attributed to preferential incorporation of long chain fatty acid from diet and/or adipose tissues, and depression of acetyl-CoA, which is needed for the synthesis of short and medium chain fatty acids [20]. Is important emphasize that palm oil at $2 \%$ and $4 \%$ (T2 and T4) caused a decrease in some fatty acids associated with coronary heart disease, which can be considered beneficial to consumers. The total content of SFA increased after adding 6\% palm oil (T6), which may be considered prejudicial for the consumers, as several SFAs are associated with coronary heart disease [31], insulin resistance [25], as well as increases in low-density lipoprotein (LDL) [24]. Although the total concentration of SFAs increased, the content of lauric and myristic acids was reduced, which may lead to benefits for consumers, since these fatty acids are associated with reductions coronary heart disease [35]. Consumption of foods with lauric acid (C12:0) is associated with increases in LDL [27], which itself is associated with coronary heart disease [25]. It is important to emphasize that palm oil reduced levels of lauric acid (C12:0), suggesting that sheep milk may serve as an alternative to humans with dyslipidemias. On the other hand, the treatment caused an increased on palmitic and stearic acid fatty acids, which is linked with heart disease, as observed by researchers [11] in cow's milk supplemented with palmitic acid. In summary, the comsumption of sheep milk after feed with palm oil at concentrations of $2 \%$ and $4 \%$ presents in treatments 2 and 4 can be considered beneficial to consumers, while the concentration of $6 \%$ present in T6 can lead harmful effects on human health.

In the present study, the supplementation with palm oil decreased the total content of PUFA in milk, while other study did not observe this difference in meat of goats after supplementation with $8 \%$ palm oil [2]. Nevertheless, this effect can be considered a negative effect of palm oil addition, since there are benefits to PUFA, including improvement in immunity [21], learning and memory [10]. PUFA are associated reduction in systemic inflammation [23], protection against atherosclerosis [19], prevention of peripheral artery disease [14], and reduction of steatohepatitis [29]. Alpha linolenic acid (C18:3 -3 ), popularly known as omega 3 , is associated with prevention and treatment of cardiovascular diseases [16], as well as the reduction of inflammation and oxidative stress caused by diabetes mellitus [13]. Thus, the reduction of PUFA levels in milk may have deleterious effects on human consumers. Content of C18:3 n-3, C18:2 c9 and C20:4 n-6 were lower in sheep milk supplemented with palm oil in study current, in aggreement with results reported by research in goat meat [2]. For example, C18:3 n-3 (alpha-linolenic acid) is considered a promising nutraceutical for the prevention of stroke [28], as well as for cardiovascular disease, type 2 diabetes, and reduction of fracture risk [33]. Thus, the addition of palm oil did not provide benefits to consumers with respect to the consumption of PUFA. The total content of MUFA was not altered by palm oil supplementation compared to the control group, but some fatty acids, as C17:1 n-7 C18:1 $\mathrm{n}-7 \mathrm{t}$, decreased. The excessive comsuption of vacenic acid $(\mathrm{C} 18: 1 \mathrm{n}-7 \mathrm{t})$ has been associated with coronary artery disease [17], and its reduction can be associated with beneficial effects of milk of sheep feed with palm oil.

\section{CONCLUSIONS}

The addition of plama oil in the diet of dairy sheep increased seric levels of triglycerides and cholesterol, as well as positively altered the composition of fatty acids in milk, making a product healthier to the consumer. The addition of $2 \%$ and $4 \%$ palm oil in the feed of dairy Lacaune sheep promoted a decrease in several SFAs after 60 days of treatment. On the other hand, the addition of $6 \%$ palm oil promoted an increase of total SFA levels after 60 days of treatment, while decreaseing total PUFA levels. This can be considered harmful to consumers, since several SFA are associ- 
ated with coronary heart diseases, and several PUFA are linked with reductions in inflammation, stroke, oxidative stress and hepatic disorders. In summary, the consumption of sheep milk who received the diets with $2 \%$ and $4 \%$ of palm oil can exert beneficial effects for consumers, but the diet with $6 \%$ of palm oil can be not recommended because of the increased total content of SFA. Therefore, the treatment 4 (4\% of palm oil) added in the diet may be an option for farmers to increase the milk yield of sheep [6], and to reduce the profile of saturated fatty acids in milk.
MANUFACTURERS

${ }^{1}$ Thermoplate. Shangai, China.

${ }^{2}$ Labtest Diagnóstica S.A. Lagoa Santa, MG, Brazil.

${ }^{3}$ Agilent Technologies Inc. Palo Alto, CA, USA.

${ }^{4}$ Supelco Inc. Bellefonte, PA, USA.

Ethical approval. This study was approved by the animal ethics committee of Universidade Tecnológica Federal do Paraná (Number protocol 047.2013).

Declaration of interest. The authors report no conflicts of interest. The authors alone are responsible for the content and writing of the paper.

\section{REFERENCES}

1 Abubakr A.R., Alimon A.R., Yaakub H., Abdullah N. \& Ivan M. 2013. Digestibility, rumen protozoa, and ruminal fermentation in goats receiving dietary palm oil by-products. Journal of the Saudi Society of Agriculturas Sciences. 12(1): 147-154.

2 Adeyemi K.D., Sazili A.Q., Ebrahimi M., Samsudin A.A., Alimon A.R., Karim R., Karsani S.A. \& Sabow A.B. 2016. Effects of blend of canola oil and palm oil on nutrient intake and digestibility, growth performance, rumen fermentation and fatty acids in goats. Animal Science Journal. 87(12): 1137-1147.

3 Allen M.S. 2000. Effects of diet on short-term regulation of feed intake by lactating dairy cattle. Journal of Dairy Science. 83(11): 1598-1624.

4 Bianchi A.E., Macedo V.P., França R.T., Lopes S.T.A., Lopes L.S., Stefani L.M., Volpato A., Lima H.L., Paiano D., Machado G. \& Da Silva A.S. 2014. Effect of adding palm oil to the diet of dairy sheep on milk production and composition, function of liver and kidney, and the concentration of cholesterol, triglycerides and progesterone in blood serum. Small Ruminant Research. 117(1) 78-83.

5 Bianchi A.E., Macedo V.P. \& Da Silva A.S. 2017. Adding palm oil to the diet of sheep alters fatty acids profile on yogurt: Benefits to consumers. Anais da Academia Brasileira de Ciências. 89(3): 2471-2478.

6 Bianchi A.E., Macedo V., Da Silva A.S. \& Silverira A.F. 2018. Effect of adding protected fat to the diet of dairy sheep on the production performance and milk composition. Revista Brasileira de Zootecnia. 47(2): 265-276.

7 Bligh E.G. \& Dyer W.J. 1959. A rapid method of total lipid extraction and purification. Canadian Journal of Biochemistry and Physiology. 37(7): 911-917.

8 Campos F.P., Nussio C.M.B. \& Nussio L.G. 2004. Methods of food analysis. Piracicaba: Fealq, 135p.

9 Castro T., Manso T., Jimeno V., Del Alamo M. \& Mantecón A.R. 2009. Effects of dietary sources of vegetable fats on performance of dairy ewes and conjugated linoleic acid (CLA) in milk. Small Ruminant Research. 84(1): 47-53.

10 Chakraborty N., Muhie S., Kumar R., Gautam A., Srinivasan S., Sowe B., Dimitrv G., Miller S., Jett M. \& Hammamieh R. 2017. Contributions of polyunsaturated fatty acids (PUFA) on cerebral neurobiology: an integrated omics approach with epigenomic focus. The Journal of Nutritional Biochemistry. 42(1): 84-94.

11 Chouinard P.Y., Girard V. \& Brisson G.J. 1998. Fatty acid profile and physical properties of milk fat from cows fed calcium saltg of fatty acids with varying unsaturation. Journal of Dairy Science. 81(3): 471-481.

12 Cottrell R.C. 1991. Introduction: nutritional aspects of palm oil. The American Journal of Clinical Nutrition. 53(7): 989-1009.

13 Dain A., Repossi G., Diaz-Gerevini G.T., Vanamala J., Das U.N. \& Eynard A.R. 2016. Long chain polyunsaturated fatty acids (LCPUFAs) and nordihydroguaiaretic acid (NDGA) modulate metabolic and inflammatory markers in a spontaneous type 2 diabetes mellitus model (Stillman Salgado rats). Lipids in Health and Disease. 15(2): 205-220.

14 Drudi L.M., Schaller M.S., Hiramoto J., Gasper W., Harris W.S., Hills N.K. \& Grenon S.M. 2017. Predictors of change in omega-3 index with fish oil supplementation in peripheral artery disease. Journal of Surgical Research. 210(1): 124-131.

15 Duarte L.M.D., Stumpf J.W., Fischer V. \& Salla L.E. 2005. Efeito de diferentes fontes de gordura na dieta de vacas Jersy sobre o consumo, a produção e a composição do leite. Revista Brasileira de Zootecnia. 34(12): 2020-2028. 
16 Galan P., Kesse-Guyot E., Czernichow S., Briancon S., Blacher J. \& Hercberg S. 2010. Effects of B vitamins and omega 3 fatty acids on cardiovascular diseases: a randomised placebo controlled trial. British Medical Journal. 341: 6273.

17 Gebauer S.K., Destaillats F., Dionisi F., Krauss R.M. \& Baer D.J. 2015. Vaccenic acid and trans fatty acid isomers from partially hydrogenated oil both adversely affect LDL cholesterol: a double-blind, randomized controlled trial. The American Journal of Clinical Nutrition. 102(10): 1339-1346.

18 Hartman L. \& Lago R.C.A. 1973. Rapid preparation of fatty acid methyl esters from lipids. Laboratory Practice. 22(3): 475-476.

19 Holy E.W., Forestier M., Richter E.K., Akhmedov A., Leiber F., Camici G.G., Mocharla P., Luscher T., Beer J.H. \& Tanner F.C. 2011. Dietary $\alpha$-linolenic acid inhibits arterial thrombus formation, tissue factor expression, and platelet activation. Arteriosclerosis, Thrombosis, and Vascular Biology. 31(11): 1772-1780.

20 Kim S.C., Adesogan A.T., Badinga L. \& Staples C.R. 2007. Effects of dietary n-6:n-3 fatty acid ratio on feed intake, digestibility, and fatty acid profiles of the ruminal contents, liver, and muscle of growing lambs. Journal of Animal Science. 85(6): 706-716.

21 Lee H.S., Barraza-Villarreal A., Biessy C., Duarte-Salles T., Sly P.D., Ramakrishnan U., Rivera J., Herceg Z. \& Romieu I. 2014. Dietary supplementation with polyunsaturated fatty acid during pregnancy modulates DNA methylation at IGF2/H19 imprinted genes and growth of infants. Physiological Genomics. 46(7): 851-857.

22 Lima S.M.V., Freitas Filho A.D., Castro A.D. \& Souza H.R.D. 2000. Desempenho da cadeia produtiva do dendê na Amazônia Legal. Manaus: SUDAM/Fundação do Desenvolvimento da UFPE, 157p.

23 Madden J., Brunner A., Dastur N. D., Tan R.M., Nash G.B., Rainger G.E., Shearman P.C., Calder P.C. \& Grimble R.F. 2007. Fish oil induced increase in walking distance, but not ankle brachial pressure index, in peripheral arterial bdisease is dependent on both body mass index and inflammatory genotype. Prostaglandins, Leu kotrienes and Essential Fatty Acids. 76(2): 331-340.

24 Mensink R.P., Zock P.L., Kester A.D. \& Katan M.B. 2003. Effects of dietary fatty acids and carbohydrates on the ratio of serum total to HDL cholesterol and on serum lipids and apolipoproteins: a meta-analysis of 60-controlled trials. The American Journal of Clinical Nutrition. 77(12): 1146-1155.

25 Micha R. \& Mozaffarian D. 2010. Saturated fat and cardiometabolic risk factors, coronary heart disease, stroke, and diabetes: a fresh look at the evidence. Lipids. 45(6): 893-905.

26 Mir Z., Goonewardene L.A., Okine E., Jaegar S. \& Scheer H.D. 1999. Effect of feeding canola oil on constituents, conjugated linoleico acid (CLA) and long chain fatty acids in goats milk. Small Ruminant Research. 33(1): 137-143.

27 Nestel P.J., Noakes M., Belling G.B., Mcarthur R. \& Clifton P.M. 1995. Effect on plasma lipids of interesterifying a mix of edible oils. The American Journal ff Clinical Nutrition. 62(7): 950-955.

28 Nguemeni C., Gouix E., Bourorou M., Heurteaux C. \& Blondeau N. 2013. Alpha-linolenic acid: A promising nutraceutical for the prevention of stroke. PharmaNutrition 1(1): 1-8.

29 Nogueira M.A., Oliveira C.P., Alves V.A.F., Stefano J.T., Dos Reis Rodrigues L.S., Torrinhas R.S., Cogliati B., Barbeiro H., Carrilho F.J. \& Waitzberg D.L. 2016. Omega-3 polyunsaturated fatty acids in treating non-alcoholic steatohepatitis: A randomized, double blind, placebo-controlled trial. Clinical Nutrition. 35(4): 578-586.

30 Pellegrini L.G., Cassanego D.B., Gusso A.P., Mattanna P. \& Silva S.V. 2012. Características físico-químicas de leite bovino, caprino e ovino. Synergismus Scyentifica. 7(1): 1-3.

31 Praagman J., De Jonge E.A., Kiefte-De Jong J.C., Beulens J.W., Sluijs I., Schoufour J.D., Hofman A., Schouw Y.T. \& Franco O.H. 2016. Dietary saturated fatty acids and coronary heart disease risk in a Dutch middle-aged and elderly population. Arteriosclerosis, Thrombosis, and Vascular Biology. 116: 307578.

32 Queiroga C.R.D.E., Maia M.D.O., Medeiros A.N.D., Costa R.G., Pereira R.Â.G. \& Bomfim M.A.D. 2010. Produção e composição química do leite de cabras mestiças Moxotó sob suplementação com óleo de licuri ou de mamona. Revista Brasileira de Zootecnia. 39(2): 204-209.

33 Rajaram S. 2014. Health benefits of plant-derived $\alpha$-linolenic acid. The American Journal of Clininical Nutriton. 100: 443S-448S.

34 Sambanthamurthi R., Sundram K. \& Tan Y. 2000. Chemistry and biochemistry of palm oil. Progress in Lipid Research. 39(4): 507-558.

35 Zong G., Li Y., Wanders A.J., Alssema M., Zock P.L., Willet W.C., Hu F.B. \& Sun Q. 2017. Intake of individual saturated fatty acids and risk of coronary heart disease in US men and women: two prospective longitudinal cohort studies. BMJ. 355: e5796. 